\section{Social conditions and urban environment associated with participation in the Ciclovia program among adults from Cali, Colombia}

\author{
Condiciones sociales y ambientes urbanos \\ asociados con la participación al programa de \\ Ciclovía en adultos en Cali, Colombia
}

Luis Fernando Gómez 1 Janeth Mosquera 2 Olga Lucia Gómez 2 José Moreno 3 Jose D. Pinzon 4 Enrique Jacoby 5 Magda Cepeda 2 Diana Celmira Parra 6
1 Facultad de Medicina, Pontificia Universidad Javeriana, Bogotá, Colombia. 2 Escuela de Salud Pública, Universidad del Valle, Cali. Colombia.

3 Escuela de Medicina y Ciencias de la Salud, Universidad del Rosario, Bogotá, Colombia.

4 Universidad Jorge Tadeo

Lozano, Bogotá, Colombia. 5 Organización

Panamericana de la Salud Washignton DC, U.S.A. 6 Washington University School of Medicine in St. Louis, St. Louis, U.S.A.

Correspondence L. F. Gómez Departamento de Medicina Preventiva y Social, Facultad de Medicina, Pontificia Universidad Javeriana. Calle 23, no 68-59, Interior 18, Apartamento 303, Bogotá, Distrito Capital

11001000, Colombia. luisefe64@yahoo.com
Abstract

The Ciclovia program (CP) has emerged as an effective initiative to promote active living in urban spaces in Latin America. This study assessed the association between social conditions, the urban environment and participation in the $\mathrm{CP}$ among adults living in the city of Cali, Colombia. A cross-sectional study was conducted in 2011 and 2012 among 719 adults aged 18 to 44. Urban environment measures were obtained using Geographic Information Systems. A multilevel logistic regression was used for the analysis. Slightly more than 7\% of participants had participated in the CP in the previous four weekends. Being male and having a high school degree were positively associated with participation in the CP. Participation in the CP was positively associated with living in neighborhoods with Ciclovia lanes. In contrast, a negative association was found among those living in neighborhoods with a presence of traffic fatalities. This study provides new insights about a recreational program that has potential health benefits in a region marked by urban inequalities in terms of opportunities for physical activity.

Motor Activity; Social Participation; Urban Health

\section{Resumen}

El programa de Ciclovía (PC) ha surgido como una iniciativa efectiva para promover actividad física en el contexto urbano de América Latina. Este estudio evaluó la asociación entre las condiciones sociales, el ambiente urbano y la participación en el PC en adultos que vivían en Cali, Colombia. Se llevó a cabo un estudio transversal en 2011 y 2012 en 719 adultos de 18 a 44 años. Se obtuvieron medidas del ambiente urbano utilizando Sistemas de Información Geográfica. Un poco más del 7\% de las personas participaron en el PC en los últimos 4 fines de semana. Ser hombre y tener un nivel de escolaridad de secundaria se asoció positivamente con la participación en el PC. Así mismo, se encontró una asociación positiva con residir en barrios con existencia de corredores con este programa. Por el contrario, la existencia de muertes por accidentes de tránsito fue negativamente asociada. Este estudio brinda nuevos conocimientos acerca de un programa recreativo que tiene beneficios potenciales para la salud, en una región marcada por desigualdades urbanas relacionadas con actividad física.

Actividad Motora; Participación Social; Salud Urbana 


\section{Introduction}

The promotion of physical activity is recognized as an integrated component of several healthy public policies that are undertaken in urban settings 1 . From the various domains of physical activity, leisure time physical activity is especially important in public health, due not only to its benefits in preventing non communicable disease but also for being consistently linked with health related quality of life 2,3,4,5,6,7,8.

In the urban context of Latin America, characterized by social fragmentation and inequalities in opportunities to engage in leisure time physical activity, the Ciclovia program (CP) has emerged as an effective initiative to promote active living 9,10,11. This initiative is characterized by closing avenues or secondary streets to motor vehicles on Sundays and public holidays, and allowing only recreational activities, such as walking and bicycling ${ }^{11}$. In the last 10 years the number of Latin American cities with the CP has increased particularly in Peru, Colombia and Mexico ${ }^{12}$. This growing interest may be partially explained by the fact that CP allows for the timebound and regular use of public spaces in urban contexts in which there are relatively low availability of public recreation facilities and public spaces 13. In addition, the CP represents an opportunity to encourage the equitable and sustainable use of public spaces, as it has the potential to change transportation behaviors in what has been called "unfreezing" 14 .

Several studies have found positive associations between participation in the $\mathrm{CP}$ and meeting physical activity recommendations in leisure time as well as having higher perceptions of social capital 15,16.

In Latin America, little is known about the associations between social conditions, urban environments and participation in the CP. The few studies in the area have been conducted in Bogota and have found that men and people who have studied at the graduate level have a higher prevalence of participation in the CP 16. In addition, another study found that proximity of $\mathrm{CP}$ corridors in a neighborhood was positively associated with participation in the program while high park density was negatively associated, possibly indicating a competing recreational option in the vicinity 17 .

Social conditions are understood in this study as social constructions which are biologically incorporated in ecological and societal contexts, affecting population patterns of health 18,19 . In this sense, this study attempts to surpass the mainstream approach that assumes that social conditions, such as gender, age and education level, are merely confounders or express only individual characteristics which are not connected with social contexts 18,19 . The urban environment is assumed as a set of attributes that involves social interactions with the urban space and comprises political, social and organizational processes 20 . Therefore, this study examines the extent to which some social conditions and urban environment attributes are associated with the participation in the CP in the city of Cali, Colombia, in order to offer specific and relevant programmatic recommendations to improve and expand this initiative.

\section{A brief overview of the city of Cali}

Cali is one of the main economic and cultural centers of Colombia with a population of approximately $2,200,000$ inhabitants 21 . The city is located in a flat valley with an average annual temperature of $24^{\circ} \mathrm{C}$ and an urban density of 193 inhabitants per hectare 21 . Similarly to other Latin American cities, the urbanization process in Cali has been characterized by accelerated and unplanned growth, accompanied by marked socioeconomic inequalities 22 . Large urban informal settlements are located throughout the city, which face significant challenges both in terms of the quality of housing but also the availability of recreational spaces, public transportation and urban safety 23 .

The CP in Cali is named Ciclovida and the first lane was launched in October near to the city's major sports facilities. Shortly afterwards, six community CPs were informally organized by resident community groups in different neighborhoods 24 .

During the first 13 years these initiatives were carried out with the support of voluntary groups and some private sector actors. In 1996 Ciclovida began to receive official support by the recently established Cali Sports' Secretariat and in 1997 all recreational activities were integrated into the same program. In the last two years Ciclovida was expanded from 37 to 60 kilometers and recreational activities such as "aerorumba" (aerobic sessions with tropical rhythms) and recreation zones for children were included 8,24. Currently, the program exists in 16 of the 22 urban districts of Cali, with an average participation of approximately 30,000 people every Sunday 24 . 


\section{Material and methods}

\section{Study and sampling design}

This was a multilevel cross-sectional analysis conducted between September 2011 and February 2012 among 729 adults that was part of a wider study aimed at examining the relationships between urban environment attributes and bicycle use for transportation among adults aged 18 to 44. The study uses a four-stage probabilistic sampling design without replacement. The primary sampling units were the urban sectors defined by the National Administrative Department of Statistics (DANE; Departamento Administrativo Nacional de Estadística) as geographic areas characterized by having the same socioeconomic status based on public utility bills and being delimited by natural and urban barriers (range area of 8,000 to $10,000 \mathrm{~m}^{2}$ ). In this study urban sectors are referred to as neighborhoods. Sixty-seven neighborhoods were probabilistically selected from a sampling frame of 860 . Two blocks were randomly selected in each neighborhood and an average of 12 households was obtained. Finally, an adult aged 18 to 44 years was randomly selected in each household following the inclusion criterion of residing at least one year in the neighborhood. The households and participants were selected using probabilistic systematic procedures. The response rate of this study was $66.9 \%$. This rate was lower in upper-middle class neighborhoods (48\%).

\section{General measurement procedures}

A face to face questionnaire was administered to the selected participants by interviewers with previous experience in population surveys. The average duration of the interviews was $24 \mathrm{~min}$ utes. All protocols and questionnaires were reviewed and approved by the Institutional Review Board of the Universidad del Valle in Cali and the participants were asked to provide informed consent before the survey.

\section{Dependent variable}

Participation in the CP was determined using the following question: "In the last 4 weekends did you participate in the Ciclovida program for sport or recreation purposes?", with response options of yes or no.

\section{Social conditions}

Considering the theoretical assumption described in the introduction, this study included the following social conditions: gender (male and female), age groups (18-29 and 30-44 years), self-perceived racial-ethnicity (mixed race, AfroColombian, white and other) and education level (incomplete high school or less, complete high school and more than high school).

Even though race is a social construction, it has practical implications on people every day. In fact, using race and ethnicity in public health studies contributes to understanding historical processes of racism and discrimination related to people's health. Cali is characterized by socioeconomic and persistent spatial segregation by race 25 . Therefore in this research, this social construction was "converted" into a variable and it was collected using images of people from different ethnic and racial groups (mixed race, AfroColombian, white and other). Participants in the study were asked to identify themselves choosing the picture that looks more similar to them. In this study, both race and ethnicity categories were used because they include skin color and ethnic identity.

The variable of gender was included in this research because differences by sex are associated not only with their biological conditions but also with differences on social roles, which has consequences on health outcomes 19 .

\section{Urban environment attributes}

Based on the empirical evidence from other studies about urban environments, participation in the $\mathrm{CP}$ and physical activity for leisure time in Colombia 17,26,27,28,29, the following urban environment variables were obtained using Geographic Information Systems (GIS): socioeconomic status of the neighborhood, public park density, presence of CP corridors, presence of bike paths and traffic fatalities. These geographic indicators were calculated in network polygons of 500 meters from the centroid of each neighborhood delimited by interception lines using the Thyssen methodology 30. The software ArcGIS version 10.1 (http:/ / www.esri.com/software/ arcgis/index.html) was used to conduct these measurement procedures. This approach was used in order to reduce spatial overlapping in some buffers due to the relatively high compactness of the city.

Socioeconomic status of the neighborhood was obtained based on the spatial stratification used by the municipality of Cali to bill public utilities and were classified in the following categories: low, middle and middle-upper 31 .

Public park density was obtained by dividing the total area of public parks in the buffers by the total area of each buffer and multiplying by 
100. This indicator was classified in tertiles in the statistical analysis. Binary variables were created to determine the presence of CP corridors (including community Ciclovidas) during Sundays (yes versus no), the presence of bike paths and reporting of traffic fatalities during the year 2011 (yes versus no). The source of this information was the Social Observatory of Cali (Observatorio Social de Cali; http://www.cali.gov.co/observatorios/). The research team made a thorough assessment of the quality of this data as well as how up-to-date it was.

\section{Statistical analysis}

Individual and GIS data were cleaned and checked for missing values prior to merging. A multilevel logistic regression model was developed using the command xtmelogit of Stata (StataCorp., College Stattion, USA). For this analysis, the ethnic group variable was recoded into three categories: white, Afro-Colombian, and mixed race/other. Public park density was classified in tertiles and new binary variables were recoded for CP corridors, bike paths and traffic fatalities (yes versus no). The model was adjusted for all individual and geographic variables considering theoreti- cal criteria and following the criteria proposed by Kleinbaum et al. 32 . This analysis assumed a random intercept form, and regression coefficients were taken as fixed. Collinearity was examined using regression diagnostic tests with none detected. All the statistical analyses were conducted using Stata 12.

\section{Results}

\section{Characteristics of the study population}

Table 1 shows selected characteristics of the participants included in this analysis. Mean age was 29.9 years $(\mathrm{SD}=7.6)$ and $53.4 \%$ of participants were aged between 30 and $44.63 \%$ were women and $83.8 \%$ had more than high school studies. Sixty-two reported to be of mixed race (mestizo or mulatto in Spanish). Average time of residence in the neighborhood was 14.2 years $(S D=10.5)$. Slightly more than $7 \%$ of participants reported participation in the $\mathrm{CP}$ program in the last four weekends.

\begin{tabular}{|c|c|c|}
\hline Characteristics & $\mathrm{n}$ & $\%$ or mean \\
\hline \multicolumn{3}{|l|}{ Age groups (years) } \\
\hline $18-29$ & 340 & $46.6 \%$ \\
\hline $30-44$ & 389 & $53.4 \%$ \\
\hline Mean age (years) & & $29.9(\mathrm{SD}=7.6)$ \\
\hline \multicolumn{3}{|l|}{ Gender } \\
\hline Female & 461 & $63.2 \%$ \\
\hline Male & 268 & $36.8 \%$ \\
\hline \multicolumn{3}{|l|}{ Ethnic groups } \\
\hline Mixed race & 453 & $62.2 \%$ \\
\hline Afro-Colombian & 128 & $17.6 \%$ \\
\hline White & 112 & $15.4 \%$ \\
\hline Other & 36 & $4.8 \%$ \\
\hline \multicolumn{3}{|l|}{ Education level } \\
\hline Incomplete high school or less (referent) & 256 & $35.1 \%$ \\
\hline Complete high school & 355 & $48.7 \%$ \\
\hline More than high school & 118 & $16.2 \%$ \\
\hline Years of residence in the neighborhood & & $14.2(\mathrm{SD}=10.5)$ \\
\hline \multicolumn{3}{|l|}{ Participation in Ciclovia program } \\
\hline Yes & 53 & $7.3 \%$ \\
\hline No & 676 & $92.7 \%$ \\
\hline
\end{tabular}




\section{Environmental measures obtained through GIS}

Table 2 displays the urban environment variables measured in the geographic polygons of neighborhoods. The majority of the selected neighborhoods belonged to low and middle socioeconomic status ( $41.8 \%$ in both categories). The buffer areas had a mean of 376 square meters $(\mathrm{SD}=$ 80,897). The mean length of CP lanes including those neighborhoods without the program was 576.6 meters $(\mathrm{SD}=1,826.5)$ and its presence was identified in $13.4 \%$ of the selected neighborhoods. Slightly more than $50 \%$ of the geographic polygons had at least one traffic fatality during the year 2011. The mean length of bike-paths was 40.4 meters $(\mathrm{SD}=193.0)$ and were present in $11.9 \%$ of the polygons.

\section{Social conditions, urban environment and participation in the $\mathrm{CP}$}

After adjusting for social conditions and urban environment attributes, the model showed that male gender was positively associated with participation in the $\mathrm{CP}(\mathrm{POR}=1.85$; 95\%CI: 1.01 3.41). Moreover, those who had completed high school were more likely to participate in this program than those with incomplete high school or less $(\mathrm{POR}=2.28$; 95\%CI: 1.03-5.09). Conversely, living in neighborhoods of middle socioeconomic status was negatively associated (POR $=0.40$; 95\%CI: 0.17-0.97). Participation in the CP was positively associated with living in neighborhoods with Ciclovia corridors (POR = 4.27; 95\%CI: 1.66-11.02). In contrast, a negative association was identified among those living in neighborhoods with reported traffic fatalities in 2011 (POR = 0.45; 95\%CI: 0.22-0.92) (Table 3).

\section{Discussion}

The findings of this study suggest that some social conditions and urban environment attributes are associated with participation in the CP among adults living in Cali. In a region like Latin America, characterized by unequal opportunities to engage in physical activity during leisure time in urban settings, this study provides evidence about a recreational program that has potential health benefits.

The positive association between being male and participating in the CP has been documented in a previous study conducted in Bogotá 12 and is also related to gender disparities consistently reported in leisure time physical activity in Latin America 33,34,35,36. A potential explanation for this

\begin{tabular}{|c|c|c|c|c|c|}
\hline Variables & $\mathbf{n}$ & Mean (SD) or \% & Median & Minimum & Maximum \\
\hline \multicolumn{6}{|c|}{ Socioeconomic status of the neighborhoods } \\
\hline Low (referent) & 28 & $41.8 \%$ & - & - & - \\
\hline Middle & 28 & $41.8 \%$ & - & - & - \\
\hline Middle-upper & 11 & $16.4 \%$ & - & - & - \\
\hline Buffer area (square meters) & & $376.0(80.8)$ & 371.7 & 176.6 & 536.0 \\
\hline Length of Ciclovia corridors (meters) & & $576.6(1826.5)$ & 0 & 0 & 7902.3 \\
\hline \multicolumn{6}{|l|}{ Presence of Ciclovia corridors } \\
\hline Yes & 9 & $13.4 \%$ & - & - & - \\
\hline No & 58 & $86.6 \%$ & - & - & - \\
\hline Public park density (percentage) & & $2.7(3.3)$ & 1.3 & 0 & 16.9 \\
\hline \multicolumn{6}{|l|}{ Traffic fatalities in the year 2011} \\
\hline Yes & 34 & $50.7 \%$ & - & - & - \\
\hline No & 33 & $49.3 \%$ & - & - & - \\
\hline Length of bike paths (meters) & & $40.4(193.0)$ & 0 & 0 & 1326.7 \\
\hline \multicolumn{6}{|l|}{ Presence of bike paths corridors } \\
\hline Yes & 8 & $11.9 \%$ & - & - & - \\
\hline No & 59 & $88.1 \%$ & - & - & - \\
\hline
\end{tabular}


Table 3

Multilevel binary logistic regressions of social conditions and urban environment attributes associated with participation in the Ciclovia program, among 729 adults. Cali, Colombia.

\begin{tabular}{|c|c|c|c|c|c|}
\hline \multirow[t]{2}{*}{ Variables } & \multirow{2}{*}{$\begin{array}{c}\text { Ciclovia } \\
\text { participation (\%) }\end{array}$} & \multicolumn{2}{|c|}{ Unadjusted model } & \multicolumn{2}{|c|}{ Adjusted model * } \\
\hline & & POR & $95 \% \mathrm{Cl}$ & POR & $95 \% \mathrm{Cl}$ \\
\hline \multicolumn{6}{|l|}{ Social conditions } \\
\hline \multicolumn{6}{|l|}{ Age groups (years) } \\
\hline $18-29$ (referent) & 5.3 & 1.00 & & 1.00 & \\
\hline $30-44$ & 8.5 & 1.68 & $0.90-3.16$ & 1.61 & $0.84-3.07$ \\
\hline \multicolumn{6}{|l|}{ Gender } \\
\hline Women (referent) & 5.5 & 1.00 & & 1.00 & \\
\hline Men & 9.7 & 1.85 & $1.01-3.39$ & 1.85 & $1.01-3.41$ \\
\hline \multicolumn{6}{|l|}{ Ethnic groups } \\
\hline \multicolumn{6}{|l|}{ (referent) } \\
\hline Afro-Colombian & 7.3 & 1.02 & $0.46-2.29$ & 1.10 & $0.49-2.49$ \\
\hline White & 6.7 & 0.84 & $0.34-2.05$ & 0.93 & $0.38-2.32$ \\
\hline \multicolumn{6}{|l|}{ Education level } \\
\hline $\begin{array}{l}\text { Incomplete high school or } \\
\text { less (referent) }\end{array}$ & 3.6 & 1.00 & & 1.00 & \\
\hline Complete high school & 8.6 & 2.53 & $1.15-5.57$ & 2.28 & $1.03-5.09$ \\
\hline More than high school & 10.1 & 2.91 & $1.11-7.60$ & 2.29 & $0.80-6.53$ \\
\hline \multicolumn{6}{|l|}{ GIS (urban environment attributes) } \\
\hline \multicolumn{6}{|l|}{ Socioeconomic status of the } \\
\hline Low (referent) & 7.5 & 1.00 & & 1.00 & \\
\hline Middle & 5.0 & 0.63 & $0.26-1.52$ & 0.40 & $0.17-0.97$ \\
\hline Middle-upper & 9.4 & 1.29 & $0.40-4.16$ & 0.75 & $0.23-2.52$ \\
\hline \multicolumn{6}{|l|}{ Public park density tertiles } \\
\hline $0.00-0.01$ & 6.2 & 1.00 & & 1.00 & \\
\hline $0.12-2.69$ & 7.5 & 1.21 & $0.50-2.96$ & 2.18 & $0.88-5.44$ \\
\hline $2.90-16.9$ & 7.4 & 1.15 & $0.47-2.84$ & 1.56 & $0.68-3.63$ \\
\hline \multicolumn{6}{|l|}{ Presence of Ciclovia program } \\
\hline No (referent) & 9.2 & 1.00 & & 1.00 & \\
\hline Yes & 15.2 & 2.94 & $1.16-7.50$ & 4.27 & $1.66-11.02$ \\
\hline \multicolumn{6}{|l|}{ Presence of bike paths } \\
\hline No (referent) & 7.2 & 1.00 & & 1.00 & \\
\hline Yes & 4.5 & 0.76 & $0.22-2.62$ & 0.66 & $0.20-2.22$ \\
\hline \multicolumn{6}{|l|}{ Traffic fatalities in the year 2011} \\
\hline No (referent) & 8.7 & 1.00 & & 1.00 & \\
\hline Yes & 5.5 & 0.59 & $0.29-1.22$ & 0.45 & $0.22-0.92$ \\
\hline
\end{tabular}

Notes: buffer of 500m around the neighborhoods delimited by interception lines cut by Thyssen methodology. GIS: Geographic information systems; POR: prevalence odds ratios.

* Model adjusted by age groups, gender, SES, ethnic group, education level, public park density, presence of Ciclovia program, presence of bike-paths, traffic fatalities and interaction terms.

Variance components. Tau: empty model $(0.586, p=0.019)$, model with individual variables $(0.485, p=0.041)$, final model (0.164, $p=0.237)$.

is the marked differences in cultural roles that are traditionally assigned to women in this region, mainly related to higher levels of household work and less autonomy in their decisions ${ }^{37}$. For instance, $14.3 \%$ of women in Cali never learned to ride a bike compared to only $1.5 \%$ among men 38 . 
In addition, a qualitative study conducted in Bogotá found that women reported a higher number of barriers to riding a bicycle compared to men, mainly related to personal and traffic safety 39 . This means that promoting bicycle use in Latin American cities may also contribute to the social empowerment of women.

Moreover, studies have found that men are more active than women in the domains of leisure time, work and transportation, but less so in the household, where women were more active than men ${ }^{40}$. In fact, in Colombia González et al. 41 reported that women were less likely to meet physical activity recommendations in all domains. This could illustrate inequalities in leisure time opportunities, and explain why being male is associated with CP participation in Cali. However, more research that focuses on gender issues (i.e. constrains to physical activity in public spaces) could contribute to identifying specific strategies to encourage women's participation in the CP program in Cali.

In comparison with participants that did not complete high school, those who reported completing high school were more likely to participate in the CP. However, this positive association was not found in those who had studied beyond high school, which may be explained by engagement in other leisure time physical activities in this population. This topic and potential explanation will require further exploration.

The negative association between residing in a middle socioeconomic status neighborhood and participation in the $\mathrm{CP}$ is in some way unexpected. This association was found even after adjusting for urban environment attributes such as presence of the $\mathrm{CP}$ and public park density. This may be due to residual confounding due to urban attributes and social conditions not measured in this study.

The relatively high magnitude of the positive association between the presence of a $\mathrm{CP}$ lane may highlight the relevance of this initiative in Latin American cities like Cali. This finding suggests that if people in Cali had more public spaces in which to be active, such as the CP, they would be willing to use them. The last quality of life survey carried out in 2012 in Cali showed that $19 \%$ of people who lived in the urban area were not satisfied with the provision of public spaces in the city and $39 \%$ were not satisfied with the availability of parks and green areas 21 . Thus, the $\mathrm{CP}$ contributes to "win public space" for people in a city where public space is scarce, even if only on Sundays and holidays.

The negative association between traffic fatalities and participation in the $\mathrm{CP}$ is a challenge for the implementation of programs aimed at increasing active recreation. Cali is experiencing a process of higher motorization mainly due to a rising number of motorcycles, which have been simultaneously linked with higher traffic accidents and fatalities 42 . Many of the CP corridors have an inflow of motor-vehicles, thus limiting accessibility to bikers and pedestrians and increasing the risk and fear of injury 38 . In consequence, our findings highlights the need to expand the $\mathrm{CP}$, but also to consider the adverse context or unintended consequences to which pedestrians and cyclists are exposed while engaging in outdoor physical activity. It is due to this fact that a concerted effort is being made by several public sectors in Cali to face these challenges and implement the Ciclovia, including the Sports Secretariat (responsible for the CP in Cali), the Health Secretariat and the transportation and public safety sectors. One of the main advantages and unique characteristics of the CP in Cali is the combination of citywide corridors as well as community Ciclovidas located within neighborhoods. This design may increase social engagement and ownership of the programs among participants, thus increasing participation and long-term sustainability.

In this study, park density was not associated with participation in the CP. One potential explanation for this finding is that the average size of neighborhood parks in Cali is relatively small 21 , which would increase the need and likelihood of people for using the Ciclovía corridor as a means to supplement space for leisure time physical activity.

Findings from this study highlight the fact that programs such as the CP should also include strategies to increase the social participation of women in order to reduce gender inequalities in physical activity. The involvement of more women leaders in the staff of the program may contribute, because they can consider barriers and incentives that are more relevant to them.

This study has several strengths. First, the study design allowed for the inclusion of areas of different socioeconomic conditions and variability in the urban environments. The use of geographic information systems provides an objective indicator of the environment and can increase the validity of the results. Finally, this is the first study evaluating the CP in Cali, thus contributing to the body of research on this topic in Latin America.

Some limitations deserve to be mentioned. First, the binary nature of the outcome variable does not allow for the establishment of associations with different levels of participation in the $\mathrm{CP}$, limiting the analytical scope of this study. Second, the small sample size and the low frequency 
of participants in the CP may have affected the statistical power. Third, the non-response rate of $33 \%$ does not rule out the possibility of selection bias which may be more likely in upper-middle socioeconomic status. Fourth, the relatively narrow age range (18 to 44 years) limits the reach of the study and the generalizability of the findings to the remaining adult population of Cali. Finally, the cross sectional design of this study does not allow for the assessment of temporality between selected exposure variables and participation in the CP. Even considering these limitations, studies such as this one are relevant for tracing inequalities linked to physical activity and recognizing the importance of alternative uses for public spaces for the promotion of physical activity.

\section{Resumo}

O programa Ciclovia (PC) surgiu como uma iniciativa eficaz para promover a atividade física no contexto urbano da América Latina. Este estudo avaliou a associação entre as condições sociais, o ambiente urbano $e$ participação no PC em adultos que vivem em Cali, Colômbia. Um estudo transversal foi realizado em 2011 e 2012, em 719 adultos com idades entre 18 e 44 anos. Medidas do ambiente urbano utilizando SIG foram obtidos. Pouco mais de 7\% das pessoas participaram do PC nos últimos quatro finais de semana. Ser do sexo masculino e ter um nível de ensino médio foi positivamente associado com a participação no PC. Da mesma forma, uma associação positiva com residência em bairros com corredores existência desse programa foi encontrada. Pelo contrário, a existência de mortes no trânsito foi negativamente associado . Este estudo fornece novos conhecimentos sobre um programa de lazer que tem benefícios de saúde potenciais em uma região marcada por desigualdades urbanas em atividade física.

Atividade Motora; Participação Social; Saúde Urbana

\section{Conclusion}

This study shows that being male, having completed high school and living in neighborhoods close to Ciclovia lanes were positively associated with participation in the CP. Conversely, living in neighborhoods of middle socioeconomic status and with reported traffic fatalities were negatively associated. Future qualitative and quantitative studies should be conducted in order to better understand the role of social conditions in explaining participation in these types of programs and also the relationships with other complementary recreational options such as the availability of green spaces and parks.

\section{Contributors}

All authors contributed to the study design, data analysis and writing of the paper.

\section{Conflict of interest}

The authors declare no conflict of interest.

\section{Acknowledgments}

This research was supported by a grant from the Departamento Administrativo de Ciencia, Tecnología e Innovación, COLCIENCIAS (Project code \# 110651929042 620449326152 - Contract \# 246-2010). Many individuals contributed to this research and their assistance is acknowledged. We would like to acknowledge the contribution of Maria Cristina Quevedo for the review of the concept of gender rule and Logan Mauney for the English review of the manuscript. 


\section{References}

1. Gómez LF, Sarmiento R, Ordoñez MF, Pardo CF, de Sá TH, Mallarino $\mathrm{CH}$, et al. Urban environment intervention linked to the promotion of physical activity: a mixed methods study applied to the urban context of Latin America. Soc Sci Med 2015; 131:18-30.

2. Sattelmair J, Pertman J, Ding EL, Kohl HW, Haskell W, Lee IM. Dose response between physical activity and risk of coronary heart disease: a meta-analysis. Circulation 2011; 124:789-95.

3. Jeon CY, Lokken RP, Hu FB, van Dam RM. Physical activity of moderate intensity and risk of type 2 diabetes: a systematic review. Diabetes Care 2007; 30:744-52.

4. Monninkhof EM, Elias SG, Vlems FA, van der Tweel I, Schuit AJ, Voskuil DW, et al. Physical activity and breast cancer: a systematic review. Epidemiology 2007; 18:137-57.

5. Wolin KY, Glynn RJ, Colditz GA, Lee IM, Kawachi I. Long-term physical activity patterns and healthrelated quality of life in U.S. women. Am J Prev Med 2007; 32:490-9

6. Tessier S, Vuillemin A, Bertrais S, Boini S, Le Bihan E, Oppert JM, et al. Association between leisuretime physical activity and health-related quality of life changes over time. Prev Med 2007; 44:202-8.

7. Chai W, Nigg CR, Pagano IS, Motl RW, Horwath C, Dishman RK. Associations of quality of life with physical activity, fruit and vegetable consumption, and physical inactivity in a free living, multiethnic population in Hawaii: a longitudinal study. Int J Behav Nutr Phys Act 2010; 7:83.

8. Gómez LF, Moreno J, Gómez OL, Carvajal R, Parra DC. Physical activity and health-related quality of life among adult women in Cali, Colombia: a cross-sectional study. Qual Life Res 2013; 22: 2351-8.

9. Sarmiento OL, Torres A, Jacoby E, Pratt M, Schmid TL, Stierling G. The Ciclovía-recreativa: a massrecreational program with public health potential. J Phys Act Health 2010; 7 Suppl 2:S163-80.

10. Montes F, Sarmiento OL, Zarama R, Pratt M, Wang G, Jacoby E, Schmid TL, et al. Do health benefits outweigh the costs of mass recreational programs? An economic analysis of four Ciclovía programs. J Urban Health 2012; 89:153-70.

11. Díaz del Castillo A, Sarmiento OL, Reis RS, Brownson R. Translating evidence to policy: urban interventions and physical activity promotion in Bogotá, Colombia and Curitiba, Brazil. Transl Behav Med 2011; 1:350-60.

12. Díaz del Castillo A, Pedraza C, González S, Díaz J, Ibarra L, Fernández D, et al. Ciclovías recreativas. A healthy epidemic. http://epiandes.uniandes.edu. co/?page_id=822 (accessed on 18/May/2013).

13. Parra D, Gómez LF, Pratt M, Samiento OL, Triche E, Mosquera J. Policy and built environment changes in Bogotá and their importance in health promotion. Indoor Built Environ 2007; 16:344-8.

14. Lugo A. How can ciclovias can unfreeze the streets and open them to equitable human infrastructure. http://bikeleague.org/sites/default/files/Unfreez ing\%20Streets.pdf (accessed on 01/Apr/2015).
15. Gómez LF, Mateus JC, Cabrera G. Leisure-time physical activity among women in a neighbourhood in Bogotá, Colombia: prevalence and sociodemographic correlates. Cad Saúde Pública 2004; 20:1103-9.

16. Torres A, Sarmiento OL, Stauber C, Zamara R. The Ciclovia and Cicloruta Programs: promising interventions to promote physical activity and social capital in Bogota, Colombia. Am J Public Health 2013; 103:e23-30

17. Cervero R, Sarmiento OL, Jacoby E, Gómez LF, Neiman A. Influences of built environments on walking and cycling: lessons from Bogotá. International Journal of Sustainable Transportation 2009; 3:203-26.

18. Krieger N. A glossary for social epidemiology. J Epidemiol Community Health 2001; 55:693-700.

19. Krieger N. Epidemiology and the people's health. New York: Oxford University Press; 2011.

20. Galea S, Freudenberg N, Vlahov D. Cities and population health. Soc Sci Med 2005; 60:1017-33.

21. Departamento Administrativo de Planeación, Alcaldía de Santiago de Cali. Cali en cifras 2011. http://www.cali.gov.co/ descargar.php?id=33101 (accessed on 18/May/2013).

22. UN-Habitat. Towards a new urban transition. http: / /www.unhabitat.org/pmss/getElectronicVersion.aspx? $\mathrm{nr}=3386 \&$ alt $=1$ (accessed on 18/ Jan/2013).

23. Ipsos NF. Encuesta de percepción: Cali cómo vamos 2012. http://www.fundacioncorona.org.co/ bajarDocDos.php?tl=1\&per=325 (accessed on 18/ Jan/2013).

24. Ávila D. Ciclovida. Tres décadas de deporte y diversión. Q’hubo 2013; 25 sep.

25. Vivas H. Persistencia de la segregación residencial y composición del capital humano por barrios en la ciudad de Cali. Ensayos sobre Política Económica $2013 ; 70: 121-55$.

26. Parra DC, Gomez LF, Fleisher N, Pinzón JD. Built environment characteristics and perceived active park use among older adults: results from a multilevel study in Bogotá. Health Place 2010; 16: 1174-81.

27. Gómez LF, Parra D, Buchner D, Brownson R, Sarmiento OL, Pinzón JD, et al. Built environment attributes and walking patterns among the elderly population in Bogotá. Am J Prev Med 2010; 30: 592-9.

28. Gomez LF, Sarmiento OL, Parra D, Schmid T, Pratt M, Jacoby E, et al. Characteristics of the built environment associated with leisure-time physical activity among adults in Bogota, Colombia: a multilevel study. J Phys Act Health 2010; 7:S182-95.

29. Parra D, Gómez LF, Sarmiento OL, Buchner D, Brownson R, Schmid T, et al. Perceived and objective neighborhood environment attributes and health related quality of life among the elderly in Bogotá. Soc Sci Med 2010; 70:1070-6.

30. Casaer J, Hermy M, Coppin P, Verhagen R. Analyzing space use patterns by Thiessen polygon and triangulated irregular network interpolation: a non parametric method for processing telemetric animal fixes. Int J Geogr Inf Sci 1999; 13:499-511. 
31. Departamento Administrativo Nacional de Estadística. Estratificación socioeconómica. https:// www.dane.gov.co/index.php?option=com_conten $\mathrm{t} \&$ view=article\&id=354\&Itemid=114 (accessed on 18/Feb/2013).

32. Kleinbaum D, Kupper L, Nizan A, Muller K. Applied regression analysis and other multivariate methods. 4th Ed. Belmont: Duxbury Press; 2008.

33. Azevedo MR, Araújo CL, Reichert FF, Siqueira FV, da Silva MC, Hallal PC. Gender differences in leisure-time physical activity. Int J Public Health 2007; 52:8-15.

34. Monteiro CA, Conde WL, Matsudo SM, Matsudo VR, Bonsenor IM, Lotufo PA. A descriptive epidemiology of leisure-time physical activity in Brazil, 1996-1997. Rev Panam Salud Pública 2003; 14: 246-54.

35. Steptoe A, Wardle J, Cui W, Bellisle F, Zotti AM, Baranyai $\mathrm{R}$, et al. Trends in smoking, diet, physical exercise, and attitudes toward health in European university students from 13 countries, 1990-2000. Prev Med 2002; 35:97-104.

36. Simoes EJ, Hallal P, Pratt M, Ramos L, Munk M, Damascena W, et al. Effects of community-based, professionally supervised intervention on physical activity levels among residents of Recife, Brazil. Am J Public Health 2009; 99:68-75.
37. Marquez DX. McAuley E. Gender and acculturation influences on physical activity in Latino adults. Ann Behav Med 2006; 31:138-44.

38. Mosquera J, Gómez OL, Gómez LF, Ordóñez J, Méndez F. Evaluación del impacto de la red de ciclo-rutas en la actividad física utilitaria en la población adulta de Cali. Cali: Universidad del Valle/ Fundación FES/Colciencias; 2013.

39. Mosquera J, Parra D, Gómez LF, Sarmiento OL, Schmid T, Jacoby E. An inside look at active transportation in Bogotá: a qualitative study. J Phys Act Health 2011; 9:776-85.

40. Talaei M, Rabiei K, Talaei Z, Amiri N, Zolfaghari B, Kabiri P, et al. Physical activity, sex, and socioeconomic status: a population based study. ARYA Atheroscler 2013; 9:51-60.

41. González S, Sarmiento O, Ramírez A, Grijalba C. Niveles de actividad física de la población colombiana: desigualdades por sexo y condición socioeconómica. Biomédica 2014; 34:447-59.

42. Cali Cómo Vamos. Informe de calidad de vida en Cali, 2012. http://calicomovamos.org.co/calico movamos/index.php?option=com_content\&view $=$ article $\&$ id $=16 \&$ Itemid $=35$ (accessed on $30 / \mathrm{Sep} /$ 2013).

Submitted on $01 /$ Jun/2014

Final version resubmitted on 16/Apr/2015

Approved on 09/Sep/2015 